\title{
Dijital İletişim Mecralarında Dezavantajlı Türlerin Sesi Olmak: Hayvanseverlerin Siyasal Katılım Faaliyetleri Üzerinde Empati ve Grup Bilincinin Rolü
}

\author{
Representing Disadvantaged Species in Digital Communication Media: The Role of Empathy and \\ Group Consciousness on the Political Participation Activities of Animal Lovers
}

Şakir Güler, Dr., Süleyman Demirel Üniversitesi, İletişim Fakültesi, Halkla İlişkiler ve Tanıtım Bölümü, E-posta:sakirguler@sdu.edu.tr / sakirguler@yandex.com

https://doi.org/10.47998/ikad.969478

Anahtar Kelimeler:

Siyasal katılım, Empati,

Grup bilinci, Çevreci hareketler, Hayvansever.
Keywords:

Political Participation, Empathy, Group Consciousness, Environmental Movements, Animal Lover.
Öz

Siyasal katılım faaliyetleri söz konusu olduğunda geleneksel öğreti, grup menfaatlerinin ve kişisel çıkarların katılım davranışlarını motive ettiğini aktarmaktadır. İnsan-merkezci yaklaşımın eleştirilmeye başlamasıyla birlikte bu geleneksel anlayıș değişikliğe uğramıştır. Günümüzde çevreci hareketler özgeci motivasyon kaynaklarıyla da katılım faaliyetleri gerçekleștirmektedir. Bu noktada sunulan araştırma, siyasal katılım davranışlarını güdüleyen motivasyon kaynaklarının her zaman insan-merkezli olmadığını, ekolojik merkezli hassasiyetlerin de dikkate alınması gereken toplumsal bir talep olduğunu görünür k1lmayı amaçlıyor. Bu amaç doğrultusunda 524 hayvansever üzerinden kesitsel olarak toplanan veriler, Yapısal Eşitlik Modeli ile analiz edilmektedir. Ulaşılan sonuçlar empati duygusunun hayvanseverlerin dijital iletişim kanallarında gerçekleştirdiği siyasal katılım faaliyetlerini oldukça güçlü bir biçimde etkilediğini göstermektedir. Empati ve grup bilinci; hayvanseverlerin dijital mecrada gündem oluşturma, siyasal temsilcilerle etkileşime geçme, boykot-yürüyüş düzenleme ve yardım faaliyeti organize etme gibi aktif katılma davranışlarını güçlü bir biçimde etkilemektedir. Üstelik katılımcıların yarısından fazlası (n288) düzenli bir gelire sahip olmayan kişilerdir. Politika yapıcıların ve yönetim temsilcilerinin bu beklentileri göz önünde bulundurması faydalı olacaktır. Çünkü böylesine aktif katılım davranışı sergileyen ve yüksek empati duygusuna sahip kitleler, demokratik süreçlerin idealize edilmesinde toplum için önem arz etmektedir.

\section{Abstract}

Virtual identity is the digital identity of the individuals that they construct according to their prThe traditional approach states that group interests and subjective interests motivate political participation behaviors when it comes to political participation activities. Since the anthropocentric paradigm began to be criticized, this traditional approach has begun to change. Today, environmental movements also carry out political participation activities with altruistic motivation sources. Therefore, this research aims to make it visible that the factors that motivate political participation behaviors are not always anthropocentric, but that ecological-centered sensitivities are also a social demand that should be taken into account. For this purpose, crosssectional data collected from 524 animal lovers are analyzed with the Structural Equation Model (SEM). The results show that empathy strongly affects the political participation activities of animal lovers in digital communication channels. Empathy and group awareness increase animal lovers' active political participation behaviors such as setting the agenda on digital platforms, interacting with political representatives, organizing boycotts-walks, and organizing aid activities. Moreover, more than half of the research population (n288) were people without a regular income. Policymakers and management representatives should consider these demands. Because groups that exhibit such active participation behavior at the social level and have a high sense of empathy contribute to the idealization of democratic processes. 


\section{Giriș}

Yirmi birinci yüzyılla birlikte insan yaşamı, giderek daha dijital bir görünüm kazanmaktadır. Demokratik toplum düzeni ve yönetim mekanizmaları bu yeni çağa uyum sağlayabilmek adına mevcudiyetlerini dijital teknolojiler üzerinde de inşa etmekteler. Dünya nüfusunun yarısından fazlası (4.66 milyar), 2021 itibariyle internet teknolojisini hayatına eklemlemiş durumdadır ve 4.20 milyar kişi ise aktif sosyal medya kullanıcısıdır (WeAreSocial, 2021a). Dijital teknolojiler vasıtasıyla etkileşim gerçekleştirenlerin sayısı her geçen gün artmaktayken, bu teknolojiler giderek insan yaşamının vazgeçilmez parçaları haline gelmiştir. Humphreys' in (2010) de dikkat çektiği üzere, artık 21. yüzyılda geleneksel medya ve realitenin dişında, sanal platformlarda da sanal bir kamusal alan söz konusudur (763-764). Yurttaşlar sahip olduğu kimlik, aidiyet bağları, politik görüşleri, tutum ve beklentileri doğrultusunda dijital gündemi belirlemektedir. Ekonomik, sosyal, siyasal ve bireysel yaşam başta olmak üzere insanlar; eğitim, sağlık, duygusal/romantik konularda sahip olduğu düşünceleri yoğun bir biçimde geniş kitlelerle paylaşmaktadır (PewResearchCenter, 2015: 2). Böylece kullanıcılar kendi fikir ve yorumlarını muhataplarına ileterek, karşılıklı etkileşime ivme kazandırmıştır (Ma \& Chan, 2014: 51).

Yurttaşların yönetim mekanizmalarının aldığı kararları etkileme faaliyetleri olarak tanımlanan siyasal katılım davranışları da, bu sonuçtan pozitif olarak etkilenmiştir. Bireyler oy kullanma, açık oturum düzenleme ya da dilekçe verme gibi geleneksel katılım faaliyetlerinin dışında, artık interaktif ortamlarda da etkin katılma davranışları gerçekleştirebilmektedir. Sosyal medyadaki canlı yayınlar, hashtag bağlantılı paylaşımlar, interaktif imza kampanyaları, viral gönderiler ve daha birçok aktivite yeni nesil siyasal katılım davranışları kapsamında değerlendirilebilmektedir (Güler ve Sezgin, 2020). Dolayısıyla bu durum dijital-siyasal iletişim çalışmaları açısından da önemli firsatlar sunmaktadır. Vatandaşlar siyasal katılım faaliyetlerini web teknolojileri aracılığıyla gerçekleştirmekteyken, politika yapıcılar da halkın taleplerini yine bu teknolojiler aracılığıyla daha etkin bir şekilde okuyabilmektedir (Güler, 2020). Vatandaşların duygu ve düşünceleri daha görünür bir hal kazanmıştır. Böylece gerek siyasal erk, gerek yurttaşlar hayata geçireceği eylemleri planlama şansına sahip olabilmektedir (Can, 2020). Ayrıca bireyler dijital teknolojiler vasitasıyla birbirlerinin sahip olduğu duygu ve düşünceler hakkında da daha yakından bilgi sahibi olabilmektedir.

Hayvan hakları savunucuları ve çevre hareketleri gibi ekolojik gruplar da sosyal medyadan etkin faydalanan topluluklar arasında yer almaktadır (Paw Guards, 2021; Greenpeace, 2021). Bu gruplar, kendi aralarında güçlü organik ve sanal bağlara sahiplerdir. Böylece sosyal medya aracılığıyla geniş bir alanda hareket kabiliyeti kazanmaktadırlar. Dolayısıyla 'empatik tutumlar' ve 'grup bilinci' gibi değişkenler bu toplulukların siyasal aktiviteleri üzerinde aktif rol oynamaktadır (Dong, 2012; Kalte, 2020). Gerek hayvan haklarının savunulmasında, gerek hukuki düzlemde hayvan haklarına yönelik yasanın çıkması hususunda ilgili gruplar belirli bir bilinç dâhilinde ortak hareket etmektedir (Paw Guards, 2021). Ayrıca hayvanların zehirlenmesi ya da işkence görmesi gibi yaşanan her türlü talihsiz durumlarda, yine söz konusu gruplar sosyal medyanın interaktif gücünden faydalanarak yaşanan gelişmelerden haberdar olmakta, yüksek empati ve sorumluluk duygusuyla toplumsal bir karşı tepki geliştirmektedir (Hakim, 2020; Paw Guards, 2021). 
Fakat ilginç bir biçimde sosyal platformlarda gerçekleştirilen onlarca paylaşıma rağmen, siyasal katılım açısından empati ve grup bilincini konu alan ampirik araştırmaların sayısı oldukça sınırlıdır (Vossen ve Valkenburg, 2016: 118; Ma ve Chan, 2014). Daha çok felsefi temelde konuya ağırlık verilmiştir. Sosyolojik açıdan ise zengin bir teorik tabana sahip olunmakla birlikte, İnsan-Hayvan Çalışmaları (Human-Animal Studies [HAS]) alanında hayvan koruma hareketlerine yönelik ampirik ilgi çok sınırlıdır. Eliasçı teori, Marksist realizm, feminizm, ekofeminizm ve sosyal inşa teorisi gibi çalışma alanları teorik açıdan ilgili konunun zengin bir bağlama sahip olduğunu göstermektedir (Munro, 2012). Bu nedenle mikro düzeyde hayvan haklarına odaklanan gruplar üzerinde ampirik çalışmaların gerçekleştirilmesine ihtiyaç vardır. Nitekim Kalte'nin (2020) 684 vegan üzerinde yaptığı araştırmanın sonuçları, bu tür grupların politik alanda oldukça aktif olduğunu, yoğun siyasal katılım faaliyeti sergilediğini ve toplumda değişim yaratmay1 amaçladıklarını ortaya koymaktadır. Bu doğrultuda sunulan araştırma, 524 hayvan sever üzerinde siyasal katılım faaliyetleri açısından empatik tutumların ve grup bilincinin rolünü test etmektedir. $\mathrm{Bu}$ yönüyle araştırma ilgili alanyazını psikolojik ve siyasal düzlemde genişletmektedir.

Bahsi geçen anlatımdan hareketle bu makale 3 bölümden oluşmaktadır. İlk bölümde; kavramsal çerçeveye yer verilmektedir. Etkili bir iletişim becerisi olarak değerlendirilen empati kavramına, psikolojik ve sosyal açılardan değinilmekte, türlerin birbirine karşı duyduğu empatinin altında yatan dinamiklerden bahsedilerek, grup bilinci kavramıyla empati arasındaki ilişkinin altı çizilmektedir. Ardından, siyasal katılım faaliyetleri üzerinde bu kavramların rolü tartışılmaktadır. Çalışmanın hipotezleri bu kavramsal zemine dayanmaktadır ve literatürde dile getirilen "ampirik bulgulara ihtiyaç duyulmaktadır" söyleminin altı çizilmektedir. Bu ihtiyaçtan hareketle literatürdeki talebe yanıt verebilmek için ikinci bölümde anket yardımıyla hayvanseverlerden (n524) kesitsel veriler toplanarak bir saha araştırması gerçekleştirilmektedir. Söz konusu araştırmada hayvanseverlerin siyasal katılım faaliyetleri üzerinde empati ve grup bilincinin rolü irdelenmektedir. Son bölümde ise; elde edilen bulgular literatürdeki çalışmalar eşliğinde yorumlanmakta ve çeşitli öneriler sunulmaktadır.

\section{Kavramsal Çerçeve}

\section{Empatik Tutumlar: Ben Bilinci ve Ötekinin Bağdaşımı}

Empati kavramının kökleri; Alman estetiğinde yer alan "einfühlung” kelimesine dayanmaktadır (Wind, 1963: 150). "Einfühlung" terimi: insanların estetik açıdan güzel bulduğu objelere kendiliklerini yansıtmalarını ifade eder (Davis, 2018: 5). Lipps (1903; 1905) bu terimi (psikolojik alana taşlyarak) ilk olarak optik illüzyonların çalışma prensiplerinde, ardından bireylerin diğer insanları tanımaya başladığı süreçlerle ilişkilendirerek kullanmıştır (akt. Davis, 2018). Böylece Titchener'in (1909) bir yüzyıl önce İngilizceye tercüme ettiği empati kavramı köklerini Lipps'in $(1903 ; 1905)$ kullandığ 1 “einfühlung”den alarak gelişim göstermiştir. Öz olarak empati bir kişinin deneyimlediği duyguları, izleyicilerin dolaylı olarak deneyimlemesini ifade eder. İzleyiciler, karşısındaki kişiyle (ya da nesneyle) özdeşim kurarak onun ne hissettiğini anlamaya çalışmaktadır. 
Fakat bu durum izleyicilerin söz konusu kişinin hislerini destekleyeceği ya da karşı geleceği anlamına gelmez (Decety ve Jackson, 2004: 71). Daha çok muhatabın duygu ve düşünceleri hakkında izleyiciye ön bilgi vermektedir. İzleyiciler sonrasında ilgi (sempati) duygusuyla bu fikirleri destekleyebilir ya da karşı çıkabilir. Sempati kavramında birey, muhatabının duygularıyla özdeşim kurarak onun içinde bulunduğu duruma karşı tepkisel bir duygu geliştirmektedir (Darwall, 1998; Wispe, 1986; Cuff vd., 2016). Bu açıdan bakıldığında, empati ve sempati kavramları arasında küçük bir ayrım söz konusudur. Örneğin; yere düşen küçük bir çocukla empati kuran kişi çocuğun yere düşmesiyle birlikte hissettiği acıya odaklanırken, sempati kuran kişi ise; çocuğun durumuna içsel bir tepki geliştirerek onun için telaşlanmaktadır. Bu yakın anlam münasebeti nedeniyle alanyazında empati; sempati ve şefkat gibi kavramlar başta olmak üzere birden fazla kavramı bünyesinde barındıran daha kapsayıcı bir terim olarak düşünülmektedir (Batson, Fultz ve Schoenrade, 1987; Preston ve Waal, 2002; Barnett ve Mann, 2013; Darwall, 1988: 261; Stotland, 1969; Mercer ve Reynolds, 2002).

Empatinin benlik bilinciyle olan ilişkisi de ironiktir. Psikolojik temelde kendilik (benlik) algısı bireyin dış dünyayı "ben” bilinciyle deneyimlemesine aracılık etmektedir, kişi bu sayede kendisi dişındaki nesneleri "öteki” olarak adlandırmaktadır (Fromm, 1995: 59). Fakat empati kavramı öz benlik ve dış dünyanın nesneleri arasındaki ayrımı bulanıklaştırır (Wispe, 1986: 316). Nitekim insanlar, algıladığ 1 ya da hayalini kurduğu şeyleri hissetme gibi doğal bir eğilime sahiptir (Titchener, 1915: 198). Bu nedenle bir gezginin hikâyesini okurken gezginin seyahat ettiği ormana dair detayları, notalara bakıldığında ortaya çıkacak müziğe dair detayları, tarihi bir mekânı ziyaret ederken geçmişte o mekânda hangi olayların yaşanmış olabileceğine dair hatıraları, birey zihninde tamamlayarak hissetme eğilimi gütmektedir. Öyle ki bu süre zarfında fiziksel ve zihinsel tepkilerin verilmesi kaçınılmazdır. Örneğin; bir trafik kazasından bahsedildiğinde o anda yaşanan korkutucu olaylar mide kaslarının gerilmesine, göz bebeklerinin büyümesine ya da nefeslerin tutulmasına sebebiyet verebilir. Benzer bir biçimde taze lezzetli bir meyve tarif edilirken, doğal bir refleksle insanlar meyveden alacağı tadı hayal edebilir ve ağzı sulanabilir. Aynı durum canlıların acı çektiği süreçlerde de geçerlidir. Acı çeken bir canlıyı gören insan, onun içinde bulunduğu zor durumla özdeşim kurma eğilimi güder. Bu özdeşim neticesinde insanlar acı çeken canlının içinde bulunduğu zor durumdan kurtarılması için ortak bir amaç tayin ederek organize olmaktadır. İnsan hakları toplulukları, hayvansever gruplar, doğal yaşam savunucuları ve daha birçok topluluk bu konuya örnek gösterilebilir. Tüm bu örneklendirmeler dâhilinde Titchener (1915: 198) herhangi bir kişinin herhangi bir bireyi/nesneyi deneyimleme eğiliminde bulunduğu süreci empati kavramıyla açıklamaktadır.

Lipps ve Titchener, empati kurulurken gözlemlenen kişinin ya da nesnenin içsel bir taklidi yapıldığını düşünmektedir. Günümüzde motor taklit olarak da isimlendirilen bu eylem neticesinde insanlar, bir başkasının duygu durumuna tanık olduğunda, örtülü bir biçimde muhatabın duygusal ipuçlarını taklit etmektedir. Böylece empati sürecini başlatan kişide de taklit ettiği muhatabındakine benzer duygular-reaksiyonlar meydana gelmektedir (Davis, 2018: 5). Mercer ve Reynolds'a (2002: 11) göre empati; karşıdaki kişinin bakış açısını ve duygularını anlamayı, bu anlayışı muhatabına ileterek teyit etmeyi ve bu doğrultuda muhatabının içinde bulunduğu zor duruma yönelik yardım sunmayı içermektedir. 
Bahsedilen arka plandan hareketle empati genel olarak iki temel boyutta (duygusal ve bilişsel) tartışılagelmiştir. Cuff ve arkadaşları bu durumu alanyazında yaptıkları geniş taramadan hareketle şöyle değerlendirir:

\footnotetext{
"Empatinin en çok tartışılan yönü belki de bilişsel ya da duygusal bir kavram olup olmadığıdır. Bilişsel empati zihin teorisi ile yakından ilgili olan başkalarının düşünce durumunu anlama yeteneğidir. Duygusal empati ise duygusal bir uyaranla ortaya çıkan duygu deneyimleriyle ilgilidir. Empati üzerine gerçekleştirilen tanımların bazıları duygusal boyuta, bazıları ise bilişsel boyuta odaklanmaktadır. Fakat genel kanaat empatinin her iki kavramı birden içerdiği yönündedir (Cuff vd., 2014: 147).”
}

Cuff ve arkadaşlarının (2014) empatinin tanımı üzerine yaptı̆̆ı kapsamlı incelemede dile getirdiği üzere empati daha çok duygusal ve bilişsel boyutlar üzerinden incelenmektedir. Öte yandan kavramı daha fazla boyutta değerlendiren araştırmalarda mevcuttur. Örneğin Morse ve arkadaşları (1992) empatiyi; duygusal, ahlaki, bilişsel ve davranışsal olmak üzere dört alt kategoride ele almaktadır' ${ }^{1}$. Kavramın oldukça kapsamlı ve karmaşık bir yapıya sahip olduğu düşünülmektedir (Mercer ve Reynolds, 2002: 10). Bu nedenle sunulan araştırma kapsamında da genel kanaatle uyumlu olarak, duygusal ve bilişsel boyutlar üzerine odaklanılmaktadır.

Decety ve Jackson (2004: 71) disiplinler arası çalışmaların empatinin daha iyi anlaşılmasına yardımcı olacağını belirtir. Bu çalışma kapsamında da empati kavramı; dijital iletişim bağlamında siyasal katılım açısından ele alınmış ve kavramın demokratik süreçler üzerindeki rolü irdelenmiştir. Mercer ve Reynolds'un (2002) da belirttiği üzere bireyler empati vasitasıyla yalnızca birbirlerinin duygu ve düşüncelerini anlamaya çalışmakla kalmayıp, aynı zamanda muhataplarının zor anlarında onlara karşı yardım sunmaktadır. Bu durumun siyasal katılım faaliyetleri üzerinde de bir etkiye sahip olması beklenir. Çünkü günümüzde sosyal medya platformlarında gerçekleştirilen paylaşımlar aracılığıyla yurttaşlar birbirlerinin duygu ve düşüncelerinden daha etkin haberdar olabilmektedir. Kişisel hassasiyet gösterilen spesifik konular, biranda sosyal medya vasıtasıyla daha geniş kitlelerin, hatta ülkelerin ana gündeminde yer alabilmektedir. Örneğin; Kasım 2020'de Samsun'da ön ayakları kesilen bir köpeğin fotoğrafının sosyal medyaya düşmesiyle birlikte köpeğin yaşadığı acıyla empati kuran duyarlı kişiler, olayın ülke gündeminde yer almasına aracılık etmişlerdir. Birçok sosyal medya hesabı haberi paylaşarak hayvan haklarına dikkat çekmiş, böylece kamuoyunda oluşan hassasiyet yetkili mercilerin de gündemine girmiştir (Samsunhaber, 2020). Fotoğrafı sosyal medyaya yükleyen kişinin başlattığ 1 duyarlılık, konunun ehemmiyeti ile birleşince insanlar empati duygusuyla kolektif bir tutum sergilemişlerdir. Nitekim insan sosyal bir varlıktır. Bu vesileyle empatik tutumların siyasal katılım faaliyetleri üzerindeki etkisi merak edilmektedir. Bahsi geçen gerekçelerden yola çıkarak takip eden bölümde, sosyal bir varlık olan insanın "grup bilinci” ve "empatik tutumları" arasındaki ilişkiye dikkat çekilmektedir.

1 Duygusal boyutta muhatabın psikolojik durumunu ya da içsel duygularını paylaşma söz konusuyken, ahlaki boyutta empatiyi motive eden etik dinamikler üzerinde durulmaktadır. Bilişsel boyutta muhatabın duygu düşüncelerini kavrama yeteneği ön plana çıkmaktadır. Davranış boyutunda ise muhatabın bakış açısını anlamak için sürdürülen iletişim süreci daha baskındır. Duygusal boyutun üzerinde daha çok durulmasına karşılık sağlıkla ilgili konularda bilişsel boyut ön plandadır. Felsefi temalarda ise ahlaki alt boyutun daha fazla önem arz ettiği ifade edilmektedir (Morse vd., 1992: 10). 


\section{Empati'den Grup Bilincine}

Empati sürecinde karşıdaki muhatabın duygu ve düşüncelerini deneyimleyen, hissetmeye çalışan kişi özne olarak adlandırılmaktadır. Alg1 Eylem Modeli'ne göre empatinin kurulduğu süre zarfında muhatap nesnenin durumunun algılanıp algılanmaması, özne ve nesne arasındaki karşılıklı ilişkinin derecesine/şiddetine bağlıdır. Özne ve nesne arasındaki ilişki ise; genelde karşılıklı bağımlılığa ve ortak amaçlara dayanmaktadır (Preston \& Wall, 2002: 4).

Görsel 1: Algı Eylem Modeli: Empati Sürecinde Özne-Nesne İlişkisi
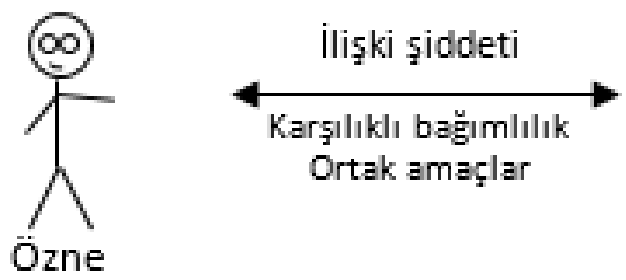

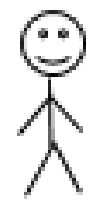

Nesne

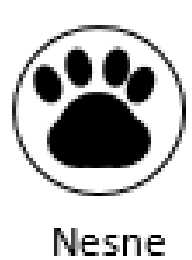

Çeşitli canlılar üzerinde yapılan deneylerde; fareler (Rice \& Gainer 1962; Rice 1964: 167), maymunlar (Masserman vd. 1964) ve güvercinler (Watanabe \& Ono 1986) başta olmak üzere birçok hayvanın kendi hemcinsiyle empati kurduğuna rastlanmaktadır. Hemcinsi zor durumda olan canlı, hemcinsinin acisını dindirmek ya da hemcinsinin beklentilerine karşılık verebilmek amacıyla çeşitli tepkiler geliştirmektedir. Bu tepkilerin derecesi, canlılar arasındaki ilişkinin gücüne ve karşılıklı bağımlılığa göre değişmektedir. Örneğin; akrabalık bağı bulunan ya da ortak amaçlara sahip deneklerin hemcinsini acıdan kurtarmak ya da beklentisine karşılık vermek amacıyla daha aktif ve yoğun çaba sarf ettiğine rastlanmaktadır (Masserman vd. 1964). Bu durum insanlar için de geçerlidir. Bebeklikten iki yaşına dek insanlar, kendi hemcinslerinin sıkıntılı durumlarına karşı ağlama yoluyla tepki verir (Simner, 1971: 147), iki yaşından sonra ise fiili yardımla empatik tepkiler geliştirir (Thompson, 1987; Stern, Botdorf, Cassidy \& Riggins, 2019). Dolayısıyla empati sürecinde muhatap özneye atfedilen bakış açısı oldukça önemlidir. Diğer bir ifadeyle insanlığın kendi hemcinslerine ve hemcinsleri dışındaki canlılara yönelik bakış açısı onları kendisiyle ne kadar yakından ilişkili gördüğü, bu canlılarla kuracağı empatik duyguların derecesi üzerinde belirleyici olmaktadır. Bu noktada grup bilinci ve kolektif algı özel bir öneme sahiptir.

Her ne kadar hayvanlar kendi hemcinsleriyle doğal bir iç güdü ile empati kuruyor olsa da, aklın insanoğluna yüklediği sorumlulukla birlikte beşeriyet, empati konusunda daha cömert olabilmektedir. Bu noktada, insanın kendisini nerede konumlandırdığı önem kazanmaktadır. İnsan-merkezli bir yaklaşım benimsenebilmekle birlikte ekoloji merkezli daha geniş bir bakış açısına da sahip olunabilir. Canlıların hepsinin birbirine bağlı ve muhtaç olduğunu öne süren derin-ekoloji merkezli bakış açısı, insanların doğaya karşı zarar veren geleneksel alışkanlıklarını terk etmesini ve çevreyle daha uyumlu politikaların 
geliştirilmesini öğütlemektedir (Drengson, Devall \& Schroll, 2010). Nitekim insanmerkezli yaklaşımdan beslenen politikalar, içinde yaşadığımız çağda birçok doğal hasara neden olmuştur (McShane, 2007: 170; Weitzenfeld \& Joy, 2014: 5). Küresel 1sınma, iklim değişikliği, canlı türlerinin yok oluşu, doğal alanların giderek azalması gibi daha birçok olumsuz gelişme bu duruma örnek gösterilebilir. Bu bağlamda Alg1 Eylem Modeli'nin de açıkladığı üzere empati sürecinde insanların muhatap özneye yüklediği anlam ve değer atfı kurulan empatinin derecesini etkilemektedir. Ayrıca gerek kutsal dinler, gerek vicdani ve ahlaki sorumluluklar, düşünen ve sorgulayan insanoğluna kendi hemcinsi dışındaki canlılara karşı da empatiyle yaklaşmasını, merhametli olmasını öğütler. Her ne kadar canlılar dünyasında farklı hayvan gruplarının da kendi türleri dışındaki canlılarla empati kurduğuna ve yardımda bulunduğuna rastlansa da, insan türü bu eylemi sistematik ve yoğun sorumluluk duygusuyla icra etmektedir.

Söz konusu deneylerden ve bahsedilen gerekçelerden hareketle grup bilincine sahip, aralarında sosyal-organik bağ bulunan ve ortak amaçlara sahip insanların karşılıklı empati düzeylerinin daha yüksek olması beklenebilir. Aynı zamanda ekoloji merkezli bakış açısına sahip kişilerin, diğer canlı türlerine karşı da daha yüksek empati duygusu besleyeceği varsayılmaktadır. Çünkü grup bilinci genellikle grup dışındaki çevrenin grup üyelerine ve grubun misyonuna karşı kötü muamele gösterdiği, dışladığı durumlarda gelişim göstermektedir. Söz konusu kötü muamele, grup üyelerinin birbirine karş1 bağlarını güçlendirerek aidiyet duygusunu kuvvetlendirir (Herrick ve Mendez, 2019).

Grup bilinci psikolojik olarak bir sosyal gruba ait olma ve bağlanma duygusudur. $\mathrm{Bu}$ duygu grubun kolektif eylem sergileyerek daha iyi statüye erişeceğini varsayar, bu nedenle grup bilincinde birlikte hareket etme misyonu etkili bir araç olarak görülmektedir (Jackman ve Jackman, 1973; Gurin vd, 1980; Miller vd., 1981). Irk, cinsiyet, sınıf ve "çeşitti amaçlar" etrafında organize olmuş topluluklar grup bilinci geliştirebilmektedir (McClain, 2009). Bu araştırmanın uygulama bölümünde de; hayvan hakları ve hayvan sevgisi için bir araya gelmiş yerel grupların geliştirdiği grup bilinci üzerine odaklanılmaktadır. Çünkü içinde yaşadığımız çağda kolektif sorunları ele almak için gelişim gösteren ekolojik hareketler ve veganlık gibi çevre-yaşam hareketleri yeni nesil siyasal katılım faaliyetleri arasında değerlendirilmektedir (Kalte, 2020: 2). Bu nedenle siyasal katılım faaliyetleri söz konusu olduğunda, empati ve grup bilinci arasındaki güçlü etkileşimi vurgulamak gerekmektedir. Üstelik çevre hareketleri ve yaşam hakkı gibi hassas konular söz konusu olduğunda, bu amaçlar etrafında birleşen toplulukların daha aktif siyasal katılım davranışı sergileyeceği düşünülmektedir (Munro, 2012).

Empati gibi diğerkâm duygular bu süreçte insanların kendileri dışındaki canlılara karşı hassasiyetlerini de siyasal katılım aktivitelerine dahil etmektedir. Böylece yalnızca insanı önceleyen talepler değil; aynı zamanda toplumu, doğayı ve tabiatı ilgilendiren hassas konularda da çeşitli dilek ve istekler yönetim kademesine iletilir. Bu açıdan bakıldığında empatik tutumlar ve siyasal katılım faaliyetleri arasında meydana gelen ilişki siyasal iletişim açısından önem arz eder. Zira bahsedildiği üzere grup dinamiklerinin etkisiyle birbirlerine ve doğaya karş1 empati düzeyi yüksek olan kişiler, toplumun diğer katmanlarına nazaran daha aktif siyasal katılım gerçekleştiriyor olabilir (ör. Lee ve Kweon, 2013; Miller vd., 1981). Ya da aynı konudan mustarip yurttaş kitleleri, sanal platformların 
sunduğu etkileşim olanakları dâhilinde bir araya gelerek bir grup bilincine sahip olabilirler (ör. Segesten ve Bossetta, 2017: 1626-1628). Bu durumda empati (insan-insan veya insancanlı arasında) ve siyasal katılım arasında pozitif yönlü ilişki beklenmektedir (H1). Bunun en çarpıcı örneğini Cho (2009: 162) acı çeken bedenler üzerinden somutlaştırmaktadır. Kamuya açık alanlarda sıra dışı bir siyasal katılım faaliyeti olarak değerlendirilebilecek olan intihar girişimlerini incelediği doktora tezinde Cho, kendini yakan kişilere karş1 kamuoyunun kayıtsız kalmadığını, empati yoluyla izleyicilerin bu marjinal katılım faaliyetine dahil olduğunu aktarmaktadır. Bu tür siyasal katılma aktiviteleri sahip olduğu duygusal amaç gereği seyircilerin gözü önünde bir başına gerçekleştirilmektedir. Buna rağmen izleyicilerin kurduğu empati neticesinde grup dinamikleri faaliyete geçmekte ve kollektif bir etki oluşmaktadır. Dolayısıyla empati ve siyasal katılım arasındaki ilişki yalnızca rasyonel aktiviteler bağlamında gerçekleşmemektedir. $\mathrm{Bu}$ nedenle bilişsel ve duygusal empati boyutlarının her biriyle siyasal katılım davranışları arasında anlamlı bir ilişki beklenmektedir (H1a-H1b-H1c-H1d-H1e-H1f).

$\mathrm{Bu}$ arka plan dâhilinde sunulan araştırmada, hayvansever yurttaşlar üzerine bir araştırma gerçekleştirilmektedir. Nitekim yurttaşlar, demokratik sistemlerde "kamuoyu" kademesini oluşturan ve grup bilinciyle yönetim mekanizmalarının aldığı siyasal kararları etkilemeye çalışan kişilerden meydana gelmektedir. Öte yandan kamuoyunu tayin eden "yönetilenler" kademesi de birden fazla alt tabakadan oluşmaktadır (Kapani, 2007). Harvey'in (2002: 6) aktarımına göre Marx bu süreçte yurttaşların hangi toplumsal sınıfa ait olduklarını fark etmelerine büyük önem atfetmektedir. Böylece yurttaşlar farkındalık kazanarak ait oldukları grupla yakın ilişkiler kurmakta ve bir sınıf bilinci meydana gelmektedir. Yanı sıra vatandaşların hangi sosyal sınıfa ait olduğunun farkında olması, onlara bir kimlik ve aidiyet duygusu da kazandırmaktadır (Gurin vd., 1980). Hayvansever kişiler bu anlamda günümüzde grup bilincine sahip, verimli bir alt kümeyi temsil etmektedir. Dolayısıyla yurttaşların ait olduğu sınıfla ve gruplarla daha yoğun empati kuracağı varsayılmaktadır. Bu durum bireylerin sahip olduğu grup bilincinin (H2) ve empatik tutumlarının (H1) siyasal katılım davranışları üzerinde anlamlı etki oluşturacağına yorulabilir. Dolayısıyla H1 ve H2 araştırmanın temel hipotezlerini oluşturmaktadır (Şekil $1)$.

\section{Araştırma Yöntemi}

Sunulan araştırma tasarımında, nicel veri toplama araçlarından anket tekniği kullanılmıştır. Veriler, kesitsel (cross-sectional) olarak 15.06.2021 - 27.06.2021 tarihleri arasında hayvansever kişiler üzerinden toplanmıştır. Araştırma; siyasal katılım davranışlarını güdüleyen motivasyon kaynaklarının her zaman insan-merkezli olmadığını, ekolojik merkezli hassasiyetlerin de dikkate alınması gereken toplumsal bir talep olduğunu görünür kılmayı amaçlamaktadır. Çalışmada veri toplama aracı olarak anket kullanılmasının amacı ise; hayvanseverlerin siyasal katılım davranışları üzerinde empatik tutumların ve grup bilincinin etkisini keşfetmektir. Bu amaç doğrultusunda veriler, online anket aracılığıyla 524 hayvansever üzerinden toplanmıştır. Analizler, IBM SPSS 24.0 ve AMOS programları aracılığıyla gerçekleştirilmiştir. Anket formu katılımcıların empatik 
tutumlarını, grup bilincini ve siyasal katılım davranışlarını ölçmeyi hedefleyen üç ayrı likert ölçeği barındırmaktadır. Yanı sıra katılımcıların demografik bilgilerine yönelik 5 sorudan oluşan form eklidir. Araştırmanın hedef evrenini; hayvansever kişiler oluşturmaktadır. Bu amaç doğrultusunda katılımcılar kartopu örnekleme yöntemiyle belirlenmiştir. Katılım göstermesi için ulaşılan hayvansever gruplar (Whatsapp, Telegram, Instagram), yeterli sayıya ulaşıncaya dek anket linkini diğer hayvansever gruplara yönlendirmiştir. İlişkisel tarama modeli kapsamında inşa edilen ve literatürdeki sınırlı çalışmalara (Cho, 2009; Lee \& Kweon, 2013; Kalte, 2020) dayanan araştırma modeli Şekil 1'de gösterilmektedir.

SK: Siyasal Katılım Değişkenleri

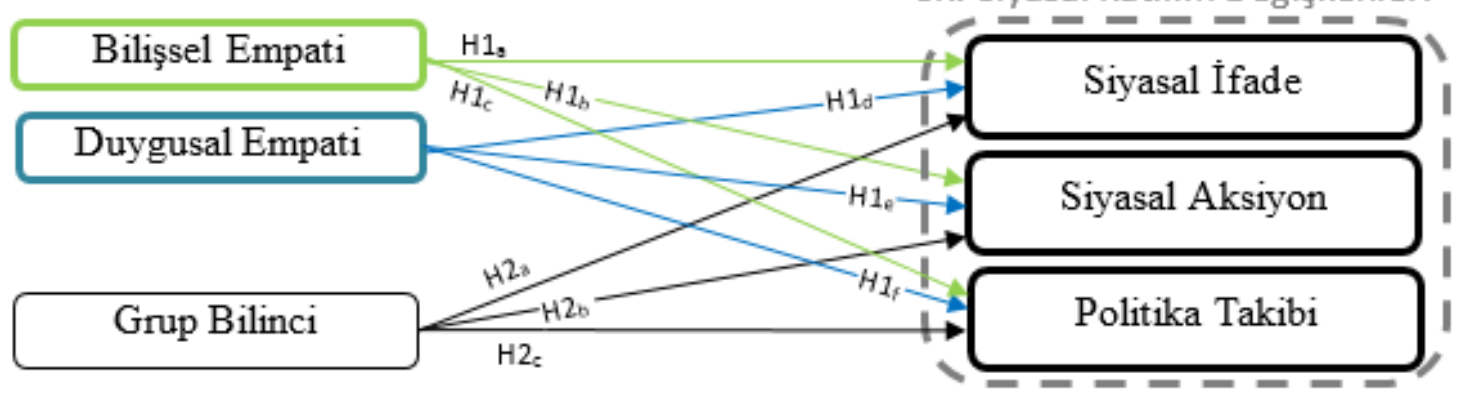

Şekil 1. Araştırma Modeli ve Hipotezler

\section{Katılımcılar ve Prosedür}

Araştırmada, hayvansever kişiler özelinde empati ve grup bilincinin siyasal katılım üzerindeki etkisine odaklanılmaktadır. Bu nedenle çalışmaya katılım şartı olarak; hayvansever olma kriteri aranmıştır. Ardından online olarak hazırlanan araştırma anketi hayvanseverlerin organize olduğu Whatsapp grupları ağırlıkta olmak üzere, Instagram ve Telegram sayfalarında paylaşılmıştır. Sorular yanıtlanmaya geçilmeden önce bilgilendirme sayfasında araştırma ile ilgili detaylar katılımcılara aktarılmış ve onayları istenmiştir. Katılımcıların, anlamadıkları soruları Whatsapp ve Telegram grupları üzerinden araştırmacıya sorabilme imkanları oluşturulmuştur. Araştırmanın gerçekleştirilmesine dair etik kurul izni 20.04.2021 tarihinde Süleyman Demirel Üniversitesi'nden alınmıştır. Katılımcılara yönelik tanımlayıcı bilgiler Tablo 1'de sunulmaktadır.

Tablo 1. Katılımcılara Dair Tanımlayıcı Bilgiler

\begin{tabular}{llll}
\hline \multirow{2}{*}{ Kategori } & Tür & Katılımcı (N) & Yüzde \% \\
\hline \multirow{2}{*}{ Cinsiyet } & Kadın & 424 & 80.9 \\
\cline { 2 - 4 } & Erkek & 100 & 19.1 \\
\hline \multirow{3}{*}{ Eğitim Durumu } & İlkokul & 2 & .4 \\
\cline { 2 - 4 } & Lise & 54 & 10.3 \\
\cline { 2 - 4 } & Lisans & 362 & 69.1 \\
\cline { 2 - 4 } & Lisansüstü & 106 & 20.2 \\
\hline \multirow{2}{*}{ Medeni Durum } & Evli & 120 & 22.8 \\
\cline { 2 - 4 } & Bekar & 404 & 77.2 \\
\hline
\end{tabular}




\begin{tabular}{|c|c|c|c|}
\hline \multirow{9}{*}{ Gelir Durumu } & Düzenli Gelirim Yok & 286 & 54.6 \\
\hline & 2825 TL (Asgari ücret) & 44 & 8.4 \\
\hline & 3000-5000 TL arasi & 62 & 11.8 \\
\hline & 5001-7000 TL aras1 & 54 & 10.3 \\
\hline & 7001-10.000 TL aras 1 & 36 & 6.9 \\
\hline & 10.001-15.000 TL aras1 & 28 & 5.3 \\
\hline & $15.001-20.000$ TL aras 1 & 8 & 1.5 \\
\hline & 20.001-50.000 TL aras1 & 4 & .8 \\
\hline & 50.000 üzeri & 2 & .4 \\
\hline
\end{tabular}

\section{Veri Toplama Araçları}

Araştırmanın amacı ve deseni doğrultusunda veri toplama aracı olarak anket tekniğinden yararlanılmıştır. Anketteki ölçme araçlarına yönelik bilgiler sırasıyla aşağıda aktarılmaktadır.

Bilişsel ve Duygusal Empati Ölçeği (BDE) [A Questionnaire of Cognitive and Affective Empathy (QCAE)]: BDE Renate vd. (2010: 87) tarafindan 640 üniversite öğrencisi üzerinde 4'lü likert² (1-Kesinlikle Katılıyorum, 4- Kesinlikle Katılmıyorum) tarzda geliştirilmiştir. Araştırmacılar ölçeğin yapı geçerliliğini (n533) empati ile ilgili alanyazındaki diğer rüştünü ispat etmiş ölçeklerle ${ }^{3}$ kıyaslayarak gerçekleştirmiştir. Ayrıca doğrulayıcı faktör analizi (DFA) ile BDE'nin yapısını doğrulamışlardır (bknz. s.90). Söz konusu alt boyutlardan perspektif alma ve çevrimiçi benzetim alt boyutları; bilişsel empati becerisini; duygusal yayılım, yakın duyarlılı, çevresel duyarlılık alt boyutları ise; duygusal empati becerisini ölçmektedir. Orijinal ölçekte BDE'nin güvenilirlik değeri alt boyutlar özelinde (cronbach's alfa) .70 ile .85 arasında değişmektedir. Ölçeğin bu çalışma kapsamındaki güvenilirlik değeri; bilişsel empati alt boyutu için $\alpha=.88$, duygusal empati alt boyutu için $\alpha=.87$ olarak hesaplanmıştır. Ayrıca her iki boyut özelinde de aracın geçerliliği DFA ile doğrulanmıştır $\left(\mathrm{X}^{2} / \mathrm{df}=2.232-2.842 ; \mathrm{p}<.001-001\right.$; RMSEA=.68-.72; $\mathrm{CFI}=.94-93$; GFI=.92-95). Ulaşılan uyum iyiliği değerleri aracın Türk popülasyonu üzerinde de geçerli ve güvenilir olduğunu teyit etmektedir.

Grup Bilinci Ölçeği (GB) / [Orijinal Kaynak: Feminist Consciousness Scale (FCS)]: GB ölçeği Duncan ve arkadaşlarının (2021) feminist bireylerin grup bilincini (FGB) ölçmek amacıyla geliştirdiği FGB aracından 5'li likert (1-Kesinlikle Katılmıyorum, 5- Kesinlikle Katıliyorum) tarzda uyarlanmıştır. FGB'den 11 madde ve yeni oluşturulan 1 madde GB ölçeğinin soru havuzunu oluşturmuştur. Ölçek soruları feminist gruplar özelinden arındırılarak hayvansever bireylere hitap edecek şekilde yapılandırılmıştır. [Ör: Çoğu feministle ortak noktam olduğunu düşünüyorum > çoğu hayvanseverle ortak noktam olduğunu düşünüyorum]. Pilot bir ön çalışma ile (n220) açıklayıcı faktör analizi (AFA) yapılmıştır. Varimax döndürme işlemi esnasında bütünle uyuşmayan 4 madde (GB4, GB6, GB7, GB9) ölçekten çıkarılmıştır. AFA'ya yönelik değerler sırasıyla; KaiserMeyer-Olkin Örneklem Uyum Ölçüsü=.883; Bartlett Küresellik Testi=840.351; Toplam Aç1klanan Varyans (sub-dim.2) $=50.645$ olarak hesaplanmıştır. Daha sonra araştırma

$2 \mathrm{Bu}$ araştırmada 5'li likert olarak uyarlanmıştır.

3 Bknz. The Trait Empathic Anger Scale - The Barratt Impulsiveness Scale - The Impulsivity Inventory - The Life History of Aggression questionnaire - The Short Expagg questionnaire - The Levenson Self-Report Psychopathy Scale - The MACH-IV 
örneklemi üzerinden toplanan verilerde GB'nin geçerliliği doğrulayıcı faktör analizi ile test edilmiştir. $\mathrm{Bu}$ aşamada ölçekle uyuşmayan 2 madde (GB5, GB11) daha ölçekten çıkarılmıştır ${ }^{4}$. Ardından ulaşılan değerlerin kabul edilebilir aralıkta olduğu gözlenmiştir $\left(\mathrm{X}^{2}=39.850 ; \mathrm{df}=13 ; \mathrm{X}^{2} / \mathrm{df}=3.065 ; \mathrm{p}<.001 ; \mathrm{RMSEA}=.72 ; \mathrm{CFI}=.92 ; \mathrm{GFI}=.95 ; \mathrm{NFI}=.92 ;\right.$ $\mathrm{IFI}=.92, \mathrm{TLI}=.92$ ). Dolayısıyla ölçek hayvanseverlerin grup bilincini ölçmek için geçerli ve güvenilirdir $(\alpha=.85)$.

Tablo 2. GB (Grup Bilinci) Ölçek Maddeleri ve Yükleri5

\begin{tabular}{llr}
\hline & \multicolumn{1}{c}{ Grup Bilinci Ölçeği Doğrulanmış Faktör Yapısı } & Yük \\
\hline GB1 & Bu ülkede hayvanların ve hayvanseverlerin başına gelen her şey beni de ilgilendirir. &, 731 \\
\hline GB2 & Çoğu hayvanseverle ortak noktam olduğunu düşünüyorum. &, 710 \\
\hline GB3 & Sık sık diğer canlıları ve onlarla ortak yönlerimi düşünürüm &, 562 \\
\hline GB8 & $\begin{array}{l}\text { Toplumumuz hayvanlara ve hayvanseverlere karşı ayrımcılık yaptığ1 için hayvanlar ve } \\
\text { hayvanseverler zor durumdadır. }\end{array}$ &, 724 \\
\hline GB10 & $\begin{array}{l}\text { Ayrımc1lik sorunlarıla başa çımanın en iyi yolu, hayvanseverlerin mümkün olduğunca organize } \\
\text { olması ve hayvanların sesi olmalarına bağlıdır. }\end{array}$ &, 530 \\
\hline GB12 & Ben bir hayvanseverim. &, 740 \\
\hline
\end{tabular}

Siyasal Katılım Ölçeği (SK): SK ölçeği yurttaşların çevrimiçi ve çevrimdışı mecralarda politik konulara katılımlarını konu almaktadır. Moreno-Jimenez vd.'nin(2013) SCAP aracı ve Güler \& Sezgin'in (2019) TSKÖ aracı kaynak alınarak uyarlanmıştır. Likert olarak ( 1 =Kesinlikle Katılmıyorum - 5=Kesinlikle Katılıyorum) seçeneklendirilen SK üç alt boyuta sahiptir. Sunulan araştırma kapsamında SK'nın güvenilirlik katsayısı cronbach alfa $=.906$ olarak hesaplanmıştır. Aracın geçerliliği ise DFA ile sınanmıştır. Ulaşılan değerler SK'nın geçerli olduğunu işaret etmektedir $\left(X^{2}=169.802 ; \mathrm{df}=59 ; \mathrm{X}^{2} /\right.$ $\mathrm{df}=2.725 ; \mathrm{p}<.001 ; \mathrm{RMSEA}=.72 ; \mathrm{CFI}=.936$; GFI=.906; NFI=.904; IFI=.937, TLI=.916). Ölçeğe ait maddeler Tablo 3 'te sunulmaktadır.

Tablo 3. Siyasal Katılım Ölçeği Maddeleri ${ }^{6}$

\begin{tabular}{llc}
\hline & \multicolumn{1}{c}{ SIYASAL IFADE } & Yük \\
\hline Sİ1 & $\begin{array}{l}\text { Belediye başkanı, vali, milletvekili, bakan ya da diğer yetkili mercileri paylaşımlarımda } \\
\text { etiketlerim. }\end{array}$ & .838 \\
\hline Sí2 & Kamuoyu önderlerine mesaj gönderirim. & .835 \\
\hline Sí3 & Kamuoyu önderlerini paylaşımlarımda etiketlerim & .812 \\
\hline Sí4 & $\begin{array}{l}\text { Belediye başkanı, vali, milletvekili, bakan ya da diğer yetkili mercilere mesaj (veya mail) } \\
\text { gönderirim. }\end{array}$ & .722 \\
\hline Sí5 & Hassas olduğum konularda sosyal medyadaki siyasal tartışmalara katılırım. & .661 \\
\hline & \multicolumn{1}{c}{ SiYYSAL AKSIYYON } & .880 \\
\hline SA1 & $\begin{array}{l}\text { Hassas olduğum konularda düzenlenen boykotlara destek veririm. (Ör: hayvanlara eziyet } \\
\text { eden markalar) }\end{array}$ & .756 \\
\hline SA2 & Hassas olduğum konularda düzenlenen kampanyalarda dilekçe imzalarım. (Ör: change.org vb) & .711 \\
\hline SA3 & Hassas olduğum konularda sosyal medyada gerçekleştirilen yardım faaliyetlerine destek veririm. \\
\hline SA4 & $\begin{array}{l}\text { Hassas olduğum konularda düzenlenen yasal gösteri yürüyüşlerine sosyal medya üzerinden destek } \\
\text { veririm. }\end{array}$ & .664 \\
\hline
\end{tabular}

4 Ölçekten çıkarılan maddeler genelde ters kodlanmış sorulardı. Benzer bağlamları ölçen düz kodlanmış maddeler ölçekte halen mevcuttur. "Hayvansever Grup Bilinci Ölçeği" grup bilincini en az hatayla ve maddeyle ölçebilmektedir.

5 Uyarlama yapılan orijinal ölçekteki madde ve faktör yükleri için bakınız: (Dunvan vd., 2021: 7-10).

6 SK ölçeğinde yer alan siyasal aksiyon faktörüne ait maddeler DFA ve YEM analizleri yapıldıktan sonra ölçekte kalan nihai 6 madde üzerinden ardışık olarak yeniden isimlendirilmiştir. Tablo 3 'te bu yeni isimlerle sunulmuştur. Öte yandan başlangıçta SA boyutuna ait soru havuzunda 9 madde mevcuttu, bu nedenle YEM modellerinde sunulan madde isimleri SA1 ila SA 9 arasında değişmektedir. 


\begin{tabular}{|c|c|c|}
\hline SA5 & $\begin{array}{l}\text { Kendi görüşümle uyuşan popüler gündemlere / \#hashtag bağlantılarına destek veririm. (Ör: } \\
\text { \#hashtaglere paylașim/retweet/beğeni yaparak vb.) }\end{array}$ & .630 \\
\hline SA6 & Kendim gibi düşünen kişileri oy kullanmaları için teşvik ederim. & .547 \\
\hline \multicolumn{3}{|c|}{ POLITIKA TAKİi் } \\
\hline PT1 & Siyasi gündemi sosyal medya üzerinden takip ederim. & .884 \\
\hline PT2 & Hükümetin ve muhalefetin faaliyetlerini sosyal medya üzerinden takip ederim. & .864 \\
\hline
\end{tabular}

\section{Analizler ve Bulgular}

Veriler IBM SPSS v24 ve AMOS v21 programlarıyla analiz edilmiştir. Parametrik testlerin uygulanıp-uygulanmamasına karar verebilmek amacıyla verilerin dağılımı incelenmiştir. Basıklık-çarpıklık (skew \pm 2 ; kurtosis \pm 3 ) ve multivariate değerleri $(t<10.0$ ) göz önünde bulundurularak, verilerin normal dağıldığı varsayılmıştır (Kim, 2013).

Tablo 4. Araştırma Değişkenlerine Yönelik Ortalama, Standart Sapma, Basıklık ve Çarpıklık Değerleri

\begin{tabular}{|c|c|c|c|c|c|c|}
\hline & $\mathbf{x}$ & Std. Sapma & Carpı & & Basık & \\
\hline & İstatisti & Istatistik & Istatis & S. Hata & İstati & S. Hata \\
\hline GRUP BİLINCİ & 4,4455 &, 48770 &,- 940 &, 164 &, 747 & 327 \\
\hline BİLİSSEL EMPATİ & 4,2136 & ,46043 &,- 677 &, 164 & 2,826 &, 327 \\
\hline $\begin{array}{l}\rightarrow \text { Perspektif Alma Alt Boyutu } \\
\quad \text { (Karşıdakini anlama/okuyabilme) }\end{array}$ & 4,0974 & ,52837 &,- 415 & , 164 & 1,166 & ,327 \\
\hline $\begin{array}{l}\rightarrow \text { Çevrimiçi Simülasyon } \\
\text { (Karar alırken karşı1daki gibi } \\
\text { düsünebilme) }\end{array}$ & 4,4228 &, 51832 & $-1,178$ & , 164 & 2,480 & ,327 \\
\hline $\begin{array}{l}\text { DUYGUSAL EMPATI } \\
\rightarrow \text { Empatik Bulaşim Alt Boyutu } \\
\rightarrow \text { Yakin Duyumsama Alt Boyutu } \\
\text { SIYASAL KATILIM } \\
\rightarrow \text { Siyasal Ifade } \\
\rightarrow \text { Siyasal Aksiyon } \\
\rightarrow \text { Politika Takibi }\end{array}$ & $\begin{array}{l}4,3265 \\
4,3014 \\
4,3767 \\
3,7671 \\
2,8009 \\
3,7671 \\
3,7603 \\
\end{array}$ & $\begin{array}{l}, 63058 \\
, 75832 \\
, 60454 \\
, 86929 \\
1,06633 \\
, 86929 \\
1,15470 \\
\end{array}$ & $\begin{array}{l}-1,365 \\
-1,454 \\
-1,165 \\
-1,110 \\
, 262 \\
-1,110 \\
-, 827\end{array}$ & $\begin{array}{l}, 164 \\
, 164 \\
, 164 \\
, 164 \\
, 164 \\
, 164 \\
, 164\end{array}$ & $\begin{array}{l}2,626 \\
2,705 \\
2,316 \\
1,352 \\
-, 714 \\
1,352 \\
-, 231\end{array}$ & $\begin{array}{l}, 327 \\
, 327 \\
, 327 \\
, 327 \\
, 327 \\
, 327 \\
, 327 \\
\end{array}$ \\
\hline
\end{tabular}

Normal dağıldığ 1 varsayılan verilere parametrik testler uygulanmıştır. Empatinin ve grup bilincinin siyasal katılım üzerindeki etkisini keşfedebilmek amaciyla tüm değişkenlerin bir arada yer aldığı Şekil 1'deki Yapısal Eşitli Modeli ${ }^{7}$ (YEM) modeli inşa edilmiştir. Ulaşılan modelin uyum değerleri ideal aralıkta yer almasına karşılık (bknz. Tablo 4) empati ve grup bilinci değişkenleri arasında meydana gelen yüksek korelasyon katsayısı nedeniyle modelde çoklu doğrusallık hatası meydana gelmiştir. $\mathrm{Bu}$ nedenle standart yol tahmin katsayıları \pm 1 'in oldukça üzerinde seyrediyordu. Egzojen değişkenler arasındaki korelasyonu modelden izole ederek; grup bilinci ve empatinin etkilerini net bir şekilde görebilmek amacıyla üç ayrı model yapılandırılmıştır. Nitekim grup bilinci ve empati arasındaki meydana gelen yüksek korelasyon "Empati'den Grup Bilincine" başlıklı kavramsal bölümdeki açıklamalarda öngörülmüştür. Dolayısıyla araştırmanın teorik zeminine uygun olarak inşa edilen alt modellerin ilkinde (Model 1) grup bilincinin, ikincisinde (Model 2) bilişsel empatinin ve üçüncüsünde (Model3) duygusal empatinin siyasal katılım üzerindeki etkisi YEM ile sınanmıştır.

7 Buradan sonraki cümlelerde YEM olarak ifade edilmektedir. 
Tablo 5. Modellere Ait Uyum Değerleri

\begin{tabular}{|c|c|c|c|c|c|c|}
\hline \multirow[b]{2}{*}{$\begin{array}{l}\text { Uyum } \\
\text { İndeksler }\end{array}$} & \multicolumn{4}{|c|}{ Elde Edilen Uyum Değerleri } & \multicolumn{2}{|c|}{ Uyum Değer Kriterleri } \\
\hline & $\begin{array}{l}\text { Genel } \\
\text { Model } \\
\text { Sekil } 1\end{array}$ & Model 1 & Model 2 & Model 3 & $\begin{array}{l}\text { Kabul Edilebilir } \\
\text { Uyum }\end{array}$ & Mükemmel Uyum \\
\hline$\overline{X^{2}}$ & 236.031 & 324.134 & 238.547 & 211.001 & $0<\mathrm{X}^{2} / \mathrm{df}<5$ & $0<\mathrm{X}^{2} / \mathrm{df}<3$ \\
\hline $\mathrm{df}$ & 120 & 129 & 98 & 84 & - & - \\
\hline $\mathrm{X}^{2} / \mathrm{df}$ & 1.967 & 2.513 & 2.434 & 2.512 & - & - \\
\hline RMSEA & .067 & .76 & .74 & .076 & $\begin{array}{l}0.00 \leq \text { RMSEA } \leq \\
0.10\end{array}$ & $0.00 \leq \mathrm{RMSEA} \leq 0.05$ \\
\hline$\overline{\text { GFI }}$ & .897 & .890 & .903 & .911 & $0.90 \leq \mathrm{GFI} \leq 1.0$ & $0.90 \leq \mathrm{GFI} \leq 1.0$ \\
\hline CFI & .941 & .910 & .938 & .940 & $0.90 \leq \mathrm{CFI} \leq 1.0$ & $0.90 \leq \mathrm{CFI} \leq 1.0$ \\
\hline NFI & .934 & .901 & .900 & .905 & $0.90 \leq \mathrm{NFI} \leq 1.0$ & $0.90 \leq \mathrm{NFI} \leq 1.0$ \\
\hline IFI & .942 & .911 & .938 & .941 & $0.90 \leq \mathrm{IFI} \leq 1.0$ & $0.90 \leq \mathrm{IFI} \leq 1.0$ \\
\hline TLI & .925 & .893 & .924 & .925 & $0.90 \leq \mathrm{TFI} \leq 1.0$ & $0.90 \leq \mathrm{TFI} \leq 1.0$ \\
\hline RFI & .928 & .904 & .895 & .900 & $0.90 \leq \mathrm{RFI} \leq 1.0$ & $0.90 \leq \mathrm{RFI} \leq 1.0$ \\
\hline
\end{tabular}

\section{Model 1'e Yönelik Sonuçlar}

Hayvanseverlerin sahip olduğu grup bilincinin siyasal katılım faaliyetleri üzerindeki etkisini test edebilmek amaciyla kurulan Model 1'in ilk aşamasında uyum değerlerinin ideal aralıkta olmadığ1 gözlemlenmiştir. Bunun üzerine SA2, SA3 ve Sİ5 maddeleri modelden çıkarıldı ve modifikasyon önerileri doğrultusunda e25-e26, e13-e16, e-22-e23 değerleri arasına kovaryans bağlantıları atanmıştır. Ardından kurulan modelin ideal uyuma sahip olduğu gözlenmiştir (Model1-Tablo5).

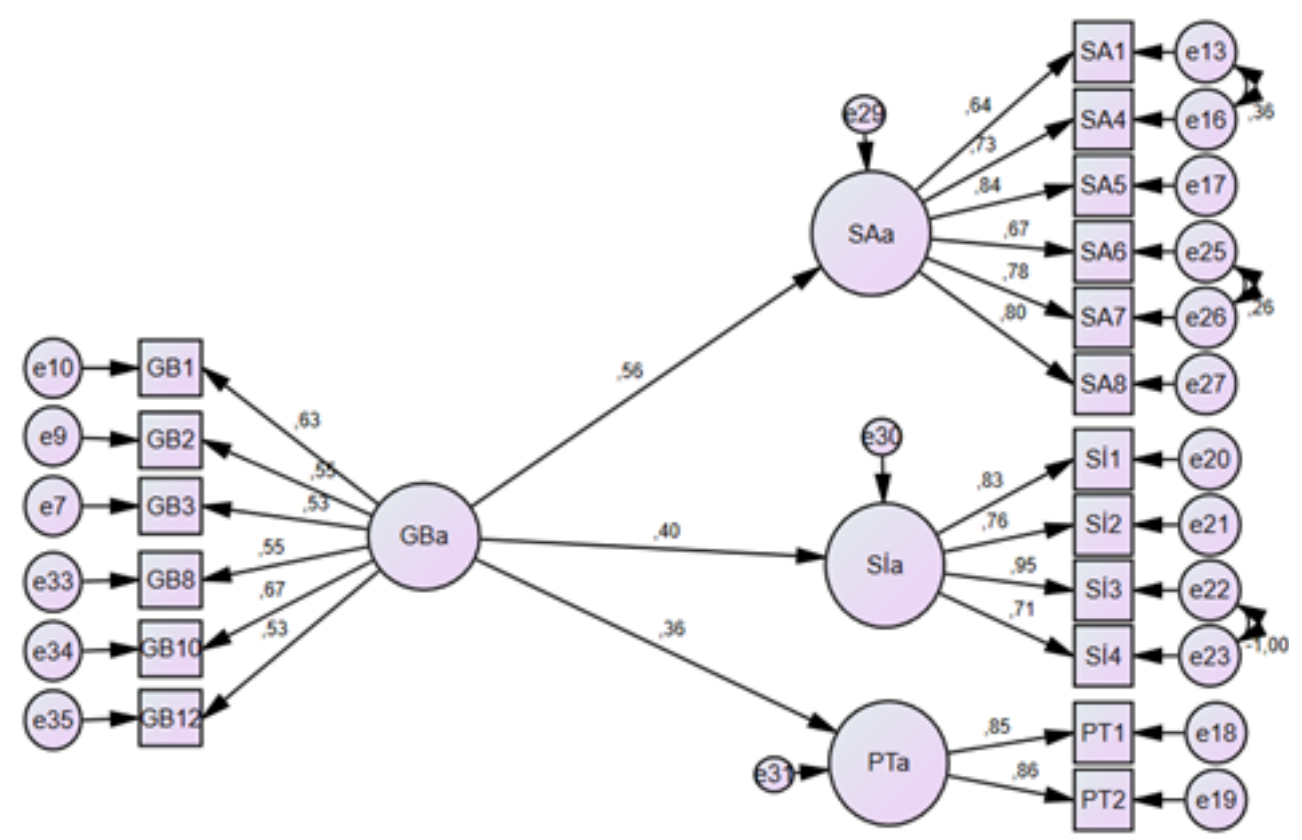

Şekil 2. Model 1'in Test Edilmesi

Ulaşılan standart tahmin katsayıları hayvanseverlerin sahip olduğu grup bilincinin siyasal katılım davranışlarını pozitif yönde etkilediğini göstermektedir. Gerçekleştirilen 
yol analizine ait beta katsayıları, $\mathrm{t}$ değerleri ve standart hata değerleri Tablo 6'te sunulmaktadir.

Tablo 6. Grup Bilincinin Siyasal Katılım Faaliyetleri Üzerine Etkisi

\begin{tabular}{|c|c|c|c|c|c|c|c|}
\hline & & & $\boldsymbol{\beta}$ & $\beta_{1}$ & S.E. & C.R. & $\mathbf{P}$ \\
\hline \multicolumn{8}{|c|}{ Yapısal Eşitlik Modeli } \\
\hline Siyasal Aksiyon & $\leftarrow$ & Grup Bilinci & 0,767 & 0,56 & 0,138 & 5,554 & $* * *$ \\
\hline Siyasal İfade & $\leftarrow$ & Grup Bilinci & 0,929 & 0,403 & 0,189 & 4,917 & $* * *$ \\
\hline Politika Takibi & $\leftarrow$ & Grup Bilinci & 0,781 & 0,358 & 0,193 & 4,057 & $* * *$ \\
\hline \multicolumn{8}{|l|}{ Ölçüm Modeli } \\
\hline GB3 & $\leftarrow$ & Grup Bilinci & 1 & 0,53 & & & \\
\hline GB2 & $\leftarrow$ & Grup Bilinci & 0,964 & 0,551 & 0,152 & 6,352 & $* * *$ \\
\hline GB1 & $\leftarrow$ & Grup Bilinci & 0,782 & 0,626 & 0,114 & 6,848 & $* * *$ \\
\hline SA1 & $\leftarrow$ & Siyasal Aksiyon & 1 & 0,636 & & & \\
\hline SA4 & $\leftarrow$ & Siyasal Aksiyon & 1,316 & 0,73 & 0,108 & 12,153 & $* * *$ \\
\hline SA5 & $\leftarrow$ & Siyasal Aksiyon & 1,602 & 0,842 & 0,15 & 10,711 & $* * *$ \\
\hline PT1 & $\leftarrow$ & Politika Takibi & 1 & 0,851 & & & \\
\hline PT2 & $\leftarrow$ & Politika Takibi & 1,048 & 0,856 & 0,176 & 5,948 & $* * *$ \\
\hline Sİ1 & $\leftarrow$ & Siyasal İfade & 1 & 0,825 & & & \\
\hline Sİ2 & $\leftarrow$ & Siyasal İfade & 0,842 & 0,764 & 0,057 & 14,872 & $* * *$ \\
\hline Sİ3 & $\leftarrow$ & Siyasal İfade & 1,186 & 0,95 & 0,069 & 17,122 & $* * *$ \\
\hline Sİ & $\leftarrow$ & Siyasal İfade & 0,827 & 0,707 & 0,073 & 11,363 & $* * *$ \\
\hline SA6 & $\leftarrow$ & Siyasal Aksiyon & 1,294 & 0,674 & 0,143 & 9,058 & $* * *$ \\
\hline SA7 & $\leftarrow$ & Siyasal Aksiyon & 1,552 & 0,776 & 0,153 & 10,123 & $* * *$ \\
\hline SA8 & $\leftarrow$ & Siyasal Aksiyon & 1,588 & 0,798 & 0,153 & 10,35 & $* * *$ \\
\hline GB8 & $\leftarrow$ & Grup Bilinci & 1,104 & 0,552 & 0,174 & 6,356 & $* * *$ \\
\hline GB10 & $\leftarrow$ & Grup Bilinci & 1,201 & 0,673 & 0,169 & 7,111 & $* * *$ \\
\hline GB12 & $\leftarrow$ & Grup Bilinci & 0,465 & 0,528 & 0,075 & 6,179 & $* * *$ \\
\hline
\end{tabular}

Tablo 6'da yer alan değerlere göre hayvanseverlerin grup bilinci, siyasal aksiyon faaliyetlerini pozitif yönde etkilemektedir $(\beta=.56 ; \mathrm{p}<.01)$. Bu sonuçtan hareketle hayvanseverlerin sahip olduğu kolektif tutumlar (grup bilinci) sayesinde etkin olarak sosyal medyada boykot düzenleyebildikleri, yürüyüşlere destek verdikleri ve popüler gündemler oluşturarak inandıkları değerleri gündemde tuttukları söylenebilir.

Benzer şekilde sosyal platformlar aracılığıyla dile getirdikleri siyasal ifadeler de grup bilincinden pozitif yönde etkilenmektedir $(\beta=.403 ; \mathrm{p}<.01)$. Grup bilinci sayesinde hayvanseverler, belediye başkanı, vali, milletvekili, bakan vb. yönetim kademelerine seslerini daha etkin duyurabilmektedir. Ayrıca grup bilicinin artmasıyla birlikte hayvanseverlerin dijital platformlar aracılığıyla politikayı daha etkin takip edecekleri beklenmektedir $(\beta=.358 ; \mathrm{p}<.01)$.

\section{Model 2’ye Yönelik Sonuçlar}

Bilişsel empatinin siyasal katılım faaliyetleri üzerindeki etkisini test edebilmek amaciyla kurulan Model 2'ye ait uyum değerleri incelenmiştir. Bunun üzerine standart tahmin katsayıları göz önünde bulundurularak, SA2 ve SA3 maddelerinin modelden çıkarılarak analiz tekrarlanmıştır. Modifikasyon önerileri doğrultusunda e20-e21, e9-e12 
arasında kovaryanslar oluşturulmuştur. Böylece kurulan modelin ideal uyum değerlerine sahip olduğu gözlenmiştir (Model2-Tablo5).

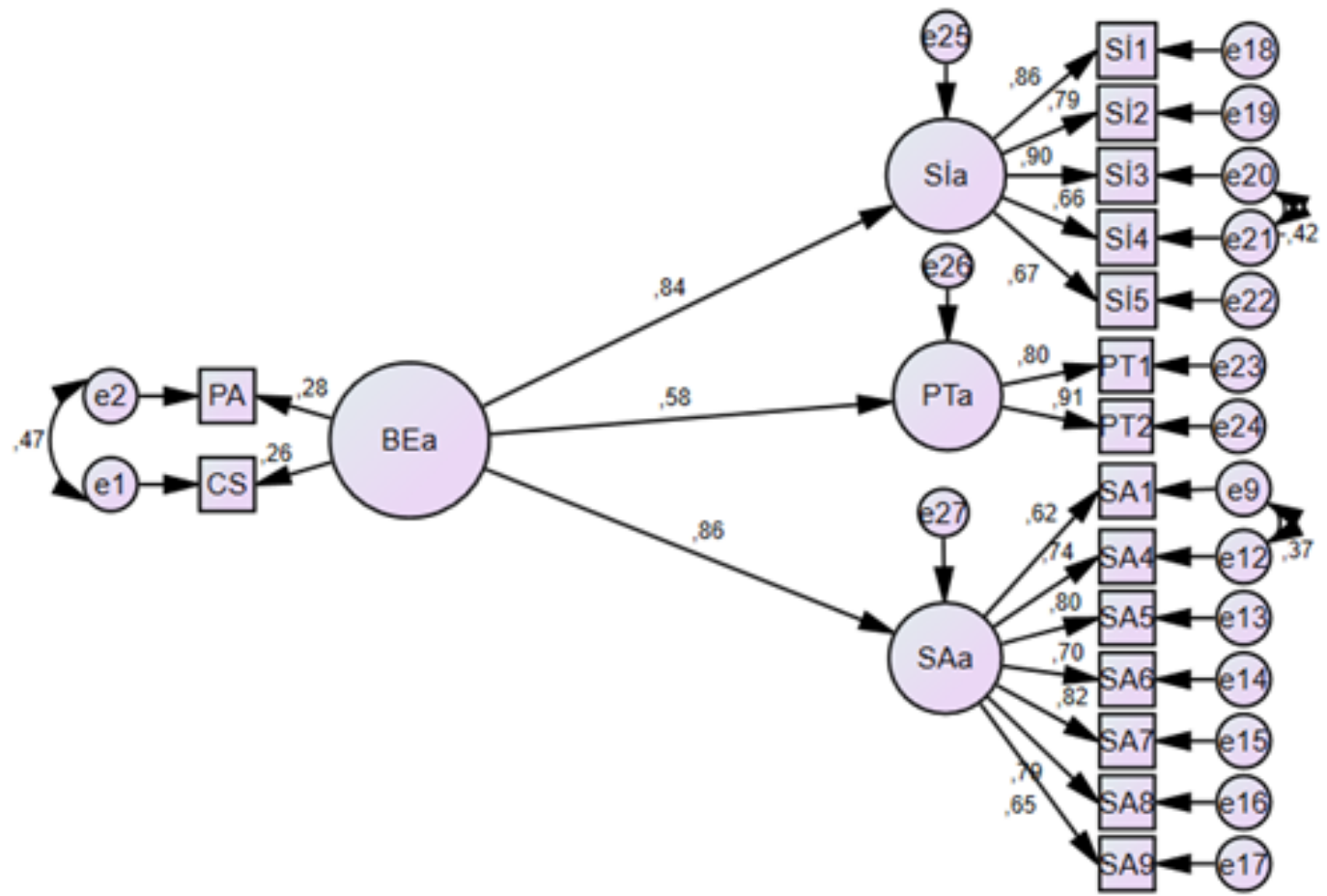

Şekil 3. Model 2'nin Test Edilmesi

Ulaşılan standart tahmin katsayıları hayvanseverlerin sahip olduğu bilişsel empatinin siyasal katılım davranışlarını pozitif yönde etkilediğini göstermektedir. Gerçekleştirilen yol analizine ait beta katsayıları, $\mathrm{t}$ değerleri ve standart hata değerleri Tablo 7'te sunulmaktadir.

Tablo 7. Bilişsel Empatinin Siyasal Katılım Faaliyetleri Üzerine Etkisi

\begin{tabular}{|c|c|c|c|c|c|c|c|}
\hline & & & $\beta$ & $\beta_{1}$ & S.E. & C.R. & $\mathbf{P}$ \\
\hline \multicolumn{8}{|c|}{ Yapısal Eşitlik Modeli } \\
\hline Siyasal İfade & $\leftarrow$ & Bilişsel Empati & 6,743 & 0,84 & 1,769 & 3,812 & $* * *$ \\
\hline Politika Takibi & $\leftarrow$ & Bilişsel Empati & 3,968 & 0,581 & 1,129 & 3,516 & $* * *$ \\
\hline Siyasal Aksiyon & $\leftarrow$ & Bilişsel Empati & 3,891 & 0,865 & 1,058 & 3,679 & $* * *$ \\
\hline \multicolumn{8}{|l|}{ Ölçüm Modeli } \\
\hline $\mathrm{CS}$ & $\leftarrow$ & Bilişsel Empati & 1 & 0,264 & & & \\
\hline PA & $\leftarrow$ & Bilişsel Empati & 1,146 & 0,275 & 0,288 & 3,972 & $* * *$ \\
\hline SA1 & $\leftarrow$ & Siyasal Aksiyon & 1 & 0,624 & & & \\
\hline SA4 & $\leftarrow$ & Siyasal Aksiyon & 1,36 & 0,74 & 0,111 & 12,216 & $* * *$ \\
\hline SA5 & $\leftarrow$ & Siyasal Aksiyon & 1,558 & 0,803 & 0,15 & 10,388 & $* * *$ \\
\hline SA6 & $\leftarrow$ & Siyasal Aksiyon & 1,372 & 0,7 & 0,146 & 9,406 & $* * *$ \\
\hline SA7 & $\leftarrow$ & Siyasal Aksiyon & 1,668 & 0,818 & 0,159 & 10,516 & $* * *$ \\
\hline SA8 & $\leftarrow$ & Siyasal Aksiyon & 1,601 & 0,788 & 0,156 & 10,252 & $* * *$ \\
\hline SA9 & $\leftarrow$ & Siyasal Aksiyon & 1,239 & 0,646 & 0,14 & 8,838 & $* * *$ \\
\hline Sİ1 & $\leftarrow$ & Siyasal İfade & 1 & 0,86 & & & \\
\hline Sİ2 & $\leftarrow$ & Siyasal İfade & 0,835 & 0,789 & 0,053 & 15,717 & $* * *$ \\
\hline Sİ3 & $\square$ & Siyasal İfade & 1,077 & 0,898 & 0,057 & 18,802 & $* * *$ \\
\hline Sİ4 & $\leftarrow$ & Siyasal İfade & 0,738 & 0,658 & 0,064 & 11,478 & $* * *$ \\
\hline Sİ5 & $\leftarrow$ & Siyasal İfade & 0,772 & 0,675 & 0,062 & 12,432 & $* * *$ \\
\hline PT1 & $\leftarrow$ & Politika Takibi & 1 & 0,797 & & & \\
\hline
\end{tabular}


\begin{tabular}{rllllll} 
PT2 & Politika Takibi & 1,196 & 0,914 & 0,125 & 9,564 & $* * *$ \\
\hline $\boldsymbol{\beta}=$ Tahmin (Estimate); $\boldsymbol{\beta} 1=$ Standart Tahmin (standart estimate); CS: çevirimiçi simülasyon (Karar
\end{tabular} alırken karşıdaki gibi düşünebilme); PA: Perspektif Alma (Karşıdakini anlama/okuyabilme); SA: Siyasal aksiyon; Sİ: Siyasal İfade; PT: Politika Takibi

Bilişsel empati (BE); bir canlının ne düşündüğünü ve hissettiğini anlama becerisi olarak değerlendirilmektedir (Cuff vd., 2014: 147). Genelde empati duygusunun atfedildiği muhatap canlı, insan olsa da bu çalışma kapsamında empati kavramıyla kastedilen hem hayvanseverlerin birbirlerine karşı gösterdiği empati, hem de hayvanseverlerin havyanlara karşı gösterdiği empatidir. Bu anlam doğrultusunda Model 2'ye ait sonuçlar hayvanseverlerin bilişsel empatilerinin siyasal katılım faaliyetlerini pozitif yönde etkilediğini göstermektedir. Siyasal ifade $(\beta=.84 ; p<.01)$ ve aksiyon $(\beta=.865 ; p<.01)$ faaliyetleri üzerinde $\mathrm{BE}$ oldukça güçlü bir etkiye sahiptir. $\mathrm{Bu}$ sonuç hayvanseverlerin düzenlediği boykot, yürüyüş, siyasal temsilcilerle etkileşim gibi katılım faaliyetlerinde BE'nin oldukça önemli bir rolü olduğunu göstermektedir. Nitekim hayvanseverlerin sahip olduğu BE düzeyi $(\mathrm{x}=4.2)$ oldukça yüksek bir seviyededir (Tablo4). Benzer bir şekilde $\mathrm{BE}$, dijital iletişim kanalları üzerinden politikayı takip etme davranışlarını da olumlu bir şekilde etkilemektedir $(\beta=.581 ; \mathrm{p}<.01)$. Dolayısıyla siyasal iletişim süreçlerinde hayvanseverlerin aktif katılım sergilemesi, bilişsel empati düzeyi ile önemli ölçüde açıklanabilmektedir.

\section{Model 3’ye Yönelik Sonuçlar}

Duygusal empatinin siyasal katılım faaliyetleri üzerindeki etkisini test edebilmek amaciyla kurulan Model 3'e ait uyum değerleri incelenmiştir. Standart tahmin katsayıları göz önünde bulundurularak, SA2, SA3, SA9 maddeleri modelden çıkarılarak analiz tekrarlanmıştır. Modifikasyon önerileri doğrultusunda e1-e2, e9-e10 arasında kovaryanslar oluşturulmuş, böylece kurulan modelin ideal uyum değerlerine sahip olduğu gözlenmiştir (Model3-Tablo5).

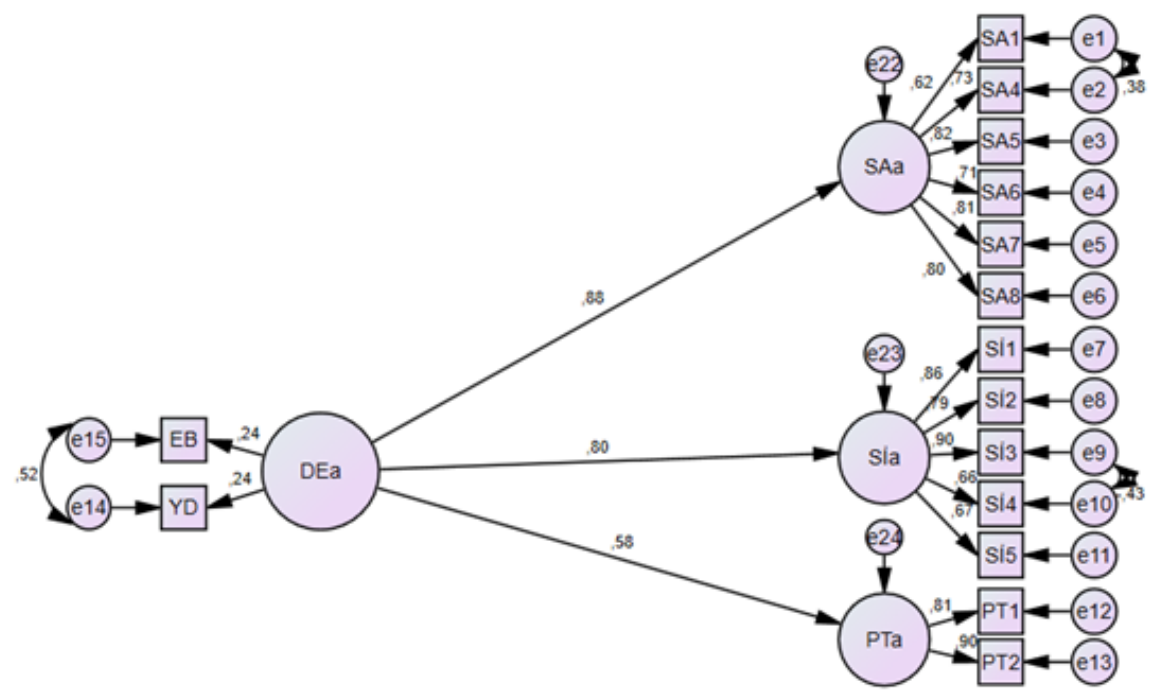

Şekil 4. Model 3'ün Test Edilmesi 
Tablo 8. Duygusal Empatinin Siyasal Katılım Faaliyetleri Üzerinde Etkisi

\begin{tabular}{|c|c|c|c|c|c|c|c|}
\hline & & & $\boldsymbol{\beta}$ & $\beta_{1}$ & S.E. & C.R. & $\mathbf{P}$ \\
\hline \multicolumn{8}{|c|}{ Yapısal Eşitlik Modeli } \\
\hline Siyasal Aksiyon & $\leftarrow$ & Duygusal Empati & 4,332 & 0,881 & 1,274 & 3,399 & $* * *$ \\
\hline Siyasal İfade & $\leftarrow$ & Duygusal Empati & 7,121 & 0,804 & 2,025 & 3,517 & $* * *$ \\
\hline Politika Takibi & $\leftarrow$ & Duygusal Empati & 4,453 & 0,583 & 1,351 & 3,297 & $* * *$ \\
\hline \multicolumn{8}{|l|}{ Ölçüm Modeli } \\
\hline SA1 & $\leftarrow$ & Siyasal Aksiyon & 1 & 0,618 & & & \\
\hline SA4 & $\leftarrow$ & Siyasal Aksiyon & 1,356 & 0,731 & 0,112 & 12,055 & $* * *$ \\
\hline SA5 & $\leftarrow$ & Siyasal Aksiyon & 1,599 & 0,817 & 0,155 & 10,345 & $* * *$ \\
\hline SA6 & $\leftarrow$ & Siyasal Aksiyon & 1,394 & 0,705 & 0,149 & 9,33 & $* * *$ \\
\hline SA7 & $\leftarrow$ & Siyasal Aksiyon & 1,671 & 0,812 & 0,162 & 10,303 & $* * *$ \\
\hline SA8 & $\leftarrow$ & Siyasal Aksiyon & 1,632 & 0,797 & 0,16 & 10,173 & $* * *$ \\
\hline Sİ1 & $\leftarrow$ & Siyasal İfade & 1 & 0,861 & & & \\
\hline Sì2 & $\leftarrow$ & Siyasal İfade & 0,832 & 0,787 & 0,053 & 15,689 & $* * *$ \\
\hline Sí3 & $\leftarrow$ & Siyasal İfade & 1,079 & 0,9 & 0,057 & 18,863 & $* * *$ \\
\hline Sİ4 & $\leftarrow$ & Siyasal İfade & 0,737 & 0,658 & 0,064 & 11,462 & $* * *$ \\
\hline Sİ5 & $\leftarrow$ & Siyasal İfade & 0,767 & 0,671 & 0,062 & 12,36 & $* * *$ \\
\hline PT1 & $\leftarrow$ & Politika Takibi & 1 & 0,808 & & & \\
\hline PT2 & $\leftarrow$ & Politika Takibi & 1,162 & 0,901 & 0,121 & 9,598 & $* * *$ \\
\hline Yakın Duyumsama & $\leftarrow$ & Duygusal Empati & 1 & 0,245 & & & \\
\hline Empatik Bulaşım & $\leftarrow$ & Duygusal Empati & 1,386 & 0,239 & 0,377 & 3,677 & $* * *$ \\
\hline
\end{tabular}

Duygusal empati (DE) bir canlının hissettiği duyguları anlamayı konu almaktadır (Cuff vd., 2014: 147). Hayvanseverlerin, hayvanlara ve birbirlerine karş1 gösterdiği duygusal empati araştırmanın teorik hipotezleriyle uyumlu olarak siyasal katılım faaliyetlerini oldukça güçlü bir biçimde etkilemiştir. Bu kapsamda DE hayvanseverlerin sosyal medya boykotlarını, yürüyüş aktivitelerine desteklerini ve sistemli popüler gündemleri oluşturmalarını anlamlı bir biçimde açıklamaktadır $(\beta=.881 ; \mathrm{p}<.01)$. Belediye başkanı vali, bakan gibi siyasal temsilcilerle etkileşimleri konu alan siyasal ifade davranışları da duygusal empatinin etkisi altındadır $(\beta=.804 ; \mathrm{p}<.01)$.

Sonuçlar, hayvanlara karşı gösterilen duygusal-bilişsel empatinin ve sahip olunan grup bilincinin siyasal katılım faaliyetleri üzerinde oldukça güçlü bir etkisi olduğunu göstermektedir. Bu kapsamda araştırma hipotezlerinin tamamı doğrulanmıştır (bknz. Şekil 1). 


\section{Tartışma ve Sonuç}

$\mathrm{Bu}$ araştırmada sağlıklı bir toplum için ön koşul olarak beliren ve önemli bir iletişim becerisi olan empati kavramı merkeze alınarak, Algı Eylem Modeli (Preston \& Wall, 2002) çerçevesinde bir saha araştırması gerçekleştirilmiştir. Bu doğrultuda mikro düzeyde empati ve grup bilinci gibi faktörlerin, siyasal katılım davranışları üzerindeki etkisi hayvanseverler özelinde gün yüzüne çıkarılmış; makro düzeyde ise çevre hareketlerinin dijital mecralardaki siyasal katılım davranışlarına dair kapsamlı bir bakış açısı sunulmuştur. İletişim çalışmaları kapsamında, disiplinler arası bir yaklaşım benimsenmiştir.

Elde edilen bulgular; hayvanseverlerin (n524) siyasal katılım taleplerinin önemli ölçüde empatik tutumlardan ve grup bilincinden etkilendiğini ortaya koymaktadır. Kalte'nin (2020) de belirttiği üzere çevreci hareketler, yoğun siyasal katılım aktivitelerinde bulunmaktadır ve toplumda önemli değişim yaratmayı amaçlarlar. Fakat hangi motivasyon kaynaklarıyla bu grupların harekete geçtiği literatürde henüz netliğe kavuşmuş değildir. Bu açıdan sunulan araştırma, güçlü ampirik bulgular ortaya koymaktadır. Ayrıca katılım faaliyetleri söz konusu olduğunda geleneksel bakış açısı, grup menfaatlerinin ve maddi çıkarların yurttaşları siyasal eylemlere güdülediğini ileri sürse de (Kapani, 2007), günümüzde hayvanseverler gibi ekoloji odaklı gruplar özgeci tutumlarla siyasal katılım davranışı sergilemektedir.

Örneğin bu çalışmaya katılım gösteren 524 hayvanseverin sahip olduğu empati düzeyi 5 üzerinden 4.25 ortalama değere sahiptir. Bilişsel empati; hayvanseverlerin boykot, yürüyüş, dijital gündem oluşturma, yardım kampanyaları düzenleme gibi siyasal aksiyon faaliyetlerini \%86,5 oranında pozitif etkilemektedir. Benzer bir biçimde muhatabın duygularını hissetmeyi konu alan duygusal empati ise; siyasal aksiyon faaliyetleri üzerinde $\% 88$ pozitif etkiye neden olmuştur (Tablo 7).

Elde edilen bulgulara göre sadece siyasal aksiyon faaliyetleri üzerinde değil; bir diğer önemli katılım faaliyeti olan siyasal temsilcilerle etkileşim (siyasal ifade) faaliyetleri üzerinde de empati değişkeni önemli açıklama gücüne sahiptir. Hayvanseverlerin siyasal ifadeleri bilişsel empatiden $\% 84$, duygusal empatiden $\% 80$ pozitif etkilenmektedir (Tablo 7). Dolayısıyla dijital platformlar aracılığıyla gerçekleştirilen siyasal katılım faaliyetlerinin büyük bir bölümünün, empati duygusuyla şekillendiği görülmüştür. Bu durum toplum kademesinde ahlaki misyon üstlenen küçük grupların siyasal katılım davranışlarını anlama açısından ayrıntılı bir bakış açısı sunmaktadır. Mercer ve Reynold'un (2002) da belirttiği üzere empati eylemi, sadece muhatabın bakış açısını ve duygularını anlamayı değil; aynı zamanda muhatabın içinde bulunduğu zor duruma yönelik yardım sunmayı da içermektedir. Bu sebeple hayvanseverler modern toplum düzeninde insan dişındaki canlıların refahını da iyileştirebilmek için siyasal katılım faaliyetleri gerçekleştirerek, hayvanların seslerini yönetim kademelerine iletmektedir. Bu sonuç, insan-merkezli paradigmanın hayvanseverler özelinde reddedildiğinin bir göstergesidir. Politika yapıcıların ve yönetim temsilcilerinin bu beklentileri göz önünde bulundurması faydalı olacaktır. Çünkü toplum kademesinde böylesine aktif katılım davranışı sergileyen ve 
yüksek empati duygusuna sahip kitleler, demokratik süreçlerin idealize edilmesi açısından da önem arz etmektedir. Üstelik bu gruplar varoluş amaçları gereği şahsi motivasyon kaynakları ile değil, diğerkam duygularla hareket etmektedir (Munro, 2012; Kalte, 2020). $\mathrm{Bu}$ nedenle dile getirdikleri talepler, toplum ve çevre yararı gözetmektedir.

Ek olarak hayvanseverler, sahip oldukları grup bilinci sayesinde günümüzde daha sistematik bir biçimde faaliyetlerini sürdürmektedir (Paw Guards, 2021; Greenpeace, 2021). Sosyal medya aracılığıyla hem grup üyeleri birbirinden haberdar olmakta, hem de hayvanlarla ilgili olumsuz gelişmeler yaşandığında daha hızlı organize olabilmekteler. $\mathrm{Bu}$ kapsamda elde edilen bulgular, hayvanseverlerin grup bilincinin sosyal medyada dile getirdikleri siyasal ifadeleri $\% 40$ oranında pozitif yönde etkilediğini göstermektedir. Yani kolektif biçimde hareket eden hayvanseverler sahip oldukları grup bilinciyle, dijital mecralarda belediye başkanı, vali, milletvekili ve diğer kamuoyu önderlerine ulaşarak hızlı gündem oluşturabilmektedir. Benzer bir biçimde siyasal aksiyon faaliyetleri arasında değerlendirilen boykot, yürüyüş düzenleme, dijital gündem oluşturma gibi katılım becerileri de grup bilincinden \%56 oranında pozitif etkilenmektedir (Tablo 6).

Çalışma, alan yazında siyasal katılım açısından empati olgusunu ele alan sınırlı literatüre katkı sağlamaktadır (Vossen ve Valkenburg, 2016: 118; Ma ve Chan, 2014). Ayrıca insan-hayvan çalışmaları alanında süregelen, amprik bulguların az olduğu (Munro, 2012; Kalte, 2020) yönündeki söyleme de ampirik çıtılar sunarak katkı sağlamaktadır. Böylece empatinin siyasal katılım faaliyetleri üzerinde güçlü bir etkiye sahip olduğu, hayvansever gruplar özelinde somutlaştırılmaktadır.

Tüm bu katkıya rağmen araştırmanın birtakım sınırlılıklara tabi olduğunu da ifade etmek gerekir. Öncelikle toplanan verilerin olasılıklı olmayan örneklem dahilinde toplandığı göz önünde bulundurulmalıdır. Bu nedenle sonuçlar tüm hayvansever kişiler üzerine genellenemez. Fakat benzer grupların siyasal katılım davranışları altında yatan motivasyon kaynaklarını anlayabilmek için verimli bir ön bilgi sağlar. Öte yandan egzojen değişkenler arasında meydana gelen doğrusallık hatası, tüm değişkenlerin tek bir modelde aynı anda analiz edilmesine izin vermemiştir. Her ne kadar teorik zemine uygun bir biçimde alt modeller ayrı bir biçimde analiz edilmiş olsa da, tüm değişkenlerin bir arada kurgulandığı YEM modeline ait sonuçlara erişilememesi de araştırmanın kısıtları arasındadır. $\mathrm{Bu}$ doğrultuda sonraki araştırmacılar, olasılıklı örneklem dahilinde daha genellenebilir çalışmalar yapabilir. Böylece ulaştıkları sonuçları, bu çalışmanın bulguları ile kıyaslayabilirler. Öte yandan benzer dezavantajlı örneklem grupları üzerinde, empatinin ve grup bilincinin siyasal katılım aktiviteleri üzerindeki rolü sorgulanarak, örneklemlerden bağımsız bir şekilde siyasal katılım süreçlerinde empati ve grup bilincinin rolü ortaya koyulabilir. Nitekim siyasal iletişim çalışmalarında empati kavramına oldukça sınırlı bir biçimde yer verilmiştir (Vossen ve Valkenburg, 2016: 118; Ma ve Chan, 2014).

\section{Kaynaklar}

Barnett, G., \& Mann, R. E. (2013). Empathy deficits and sexual offending: A model of obstacles to empathy. Aggression and violent behavior, 18(2), 228-239. 
Batson, C. D., Fultz, J., Schoenrade, P. A. (1987). Distress and empathy: Two qualitatively distinct vicarious emotions with different motivational consequences. Journal of Personality, 55, 19-39.

Can, A. [AmirCAN76147523]. (2020, 2 Eylül). Sağlık çalışanları olarak bir araya gelmeliyiz. Telegram grubumuzun linki aşağıda belirtilmiştir. Sayımız ne kadar çok olursa o kadar güçlü sesimiz çıkar. [Tweet]. Erişim adresi: https://twitter.com/ AmirCAN76147523/status/1301130821902966784.

Cho, Y. C. (2009). The Politics of Suffering in the Public Sphere: The Body in Pain, Empathy, and Political Spectacles. University of Iowa.

Cuff, B. M., Brown, S. J., Taylor, L., \& Howat, D. J. (2016). Empathy: A review of the concept. Emotion review, 8(2), 144-153.

Darwall, S. (1998). Empathy, sympathy, care. Philosophical Studies: An International Journal for Philosophy in the Analytic Tradition, 89(2/3), 261-282.

Davis, M. H. (2018). Empathy: A social psychological approach. Routledge.

Decety, J., \& Jackson, P. L. (2004). The functional architecture of human empathy. Behavioral and cognitive neuroscience reviews, 3(2), 71-100.

Dong, W. (2012). Discourse right and participation: using application for hunting permits for foreigners at Dulan International Hunting Ground as a case study. Journal of Cambridge Studies, 7(1), 83-91.

Drengson, A., Devall, B., \& Schroll, M. (2010). The deep ecology movement: Origins, development, and future prospects (toward a transpersonal ecosophy). International Journal of Transpersonal Studies, 30(1-2), 101-117.

Duncan, L. E., Garcia, R. L., \& Teitelman, I. (2021). Assessing politicized gender identity: Validating the Feminist Consciousness Scale for men and women. The Journal of Social Psychology, 1-23.

Fromm, E. (1955). Sane society. New York: A Fawcett Premier Book.

Greenpeace Türkiye [Greenpeace_Med]. (2021, Mayıs 28). Açık denizlerde "Ölüm Duvarı" diye bilinen devasa balıkçılık ağları yunusları, vatozları, köpek balıklarını avliyor. İnsan faaliyetlerine kapalı okyanus koruma alanları talep ediyoruz. İmza ver, gezegenimiz için birlikte tarih yazalım! http://okyanuslarikoru.org. [video ekli] [Tweet]. Twitter. https://twitter.com/Greenpeace_Med/status/1398189668282343425

Gurin, P., Miller, A. H., \& Gurin, G. (1980). Stratum identification and consciousness. Social Psychology Quarterly, 30-47.

Güler, Ş. (2020a). Political participation and subjective well-being: individuals'eparticipation activities on twitter in terms of life satisfaction. Çukurova Üniversitesi Sosyal Bilimler Enstitüsü Dergisi, 29(4), 354-372.

Hakim - Hayvan Hakları İzleme Komitesi [@hakim_komite]. (2020, Kasım 22). Hayvanların yaşadıkları zulmü önlemek için atılması gereken ilk adım Hayvan Hakları 
Yasası'nın çıkması, bu artık çok açık. Yasanın çıkması için daha ne olması gerekiyor? Biz bu soruyu daha kaç kere soracağız? Yeter artık! \#YasaHemen. [resim ekli] [Tweet]. Twitter. https://twitter.com/hakim_komite/status/1330576058177957888

Harvey, D. (2002). Sınıfsal yapı ve mekânsal farklılaşma kuramı. Ayten Alkan, Bülent Duru (Der. ve Çev.), 20. Yüzyıl Kenti, İmge Yayınevi, Ankara, 2002, s. 147-172.

Herrick, R., \& Mendez, J. M. (2019). One Model Does Not Fit All: Group Consciousness and the Political Participation and Attitudes of American Indians. Social Science Quarterly, 100(5), 1577-1592.

Humphreys, L. (2010). Mobile social networks and urban public space. New Media \& Society, 12(5), 763-778.

Jackman, M. R., \& Jackman, R. W. (1973). An interpretation of the relation between objective and subjective social status. American sociological review, 569-582.

Kapani, M. (2007). Politika bilimine giriş. Ankara: Bilgi Kitabevi.

Kim, H. Y. (2013). Statistical notes for clinical researchers: assessing normal distribution (2) using skewness and kurtosis. Restorative dentistry \& endodontics, 38(1), 52-54.

Kweon, S. H., \& Lee, S. Y. (2013). A study on empathy, credibility, and political attitude in social media: Focused on the relationship between empathetic intention and the motivation of belonging on intended pro-social and political behavior. Advances in Journalism and Communication, 1(03), 26.

Lipps, T. (1903). Einfühlung, inner Nachanhmung, ung Organ-umpfindungen. Archiv für die gesamte Psychologie, 2, 185-204.

Lipps, T. (1905). Das Wissen von frenden Ichen. Psychologische Untersuchungen, 4, 694-722.

Loader, B. D., \& Mercea, D. (2011). Networking democracy? Social media innovations and participatory politics. Information, communication \& society, 14(6), 757769.

Ma, W. W., \& Chan, A. (2014). Knowledge sharing and social media: Altruism, perceived online attachment motivation, and perceived online relationship commitment. Computers in Human Behavior, 39, 51-58.

Masserman, J. H., Wechkin, S. \& Terris, W. (1964) "Altruistic" behavior in rhesus monkeys. American Journal of Psychiatry 121:584-85.

McShane, K. (2007). Anthropocentrism vs. nonanthropocentrism: Why should we care?. Environmental Values, 169-185.

Miller, A. H., Gurin, P., Gurin, G., \& Malanchuk, O. (1981). Group consciousness and political participation. American journal of political science, 25(3), 494-511.

Morse, J. M., Anderson, G., Bottorff, J. L., Yonge, O., O’Brien, B., Solberg, S. M., 
\& McIlveen, K. H. (1992). Exploring empathy: a conceptual fit for nursing practice?. Image: The journal of nursing scholarship, 24(4), 273-280.

Munro, L. (2012). The animal rights movement in theory and practice: A review of the sociological literature. Sociology Compass, 6(2), 166-181.

Paw Guards [@PawGuardsTr]. (2021, Haziran 3). Onlar için ses olmak zorundayız. Lütfen destek olun. Paylaşın paylaştırın. Saat tam 16.00'da aynı anda \#hayvanhaklariyasasihemen [resim ekli] [Tweet]. Twitter. https://witter.com/ PawGuardsTr/status/1400394671772344326

Preston, S. D., de Waal, F. B. (2002). Empathy: Its ultimate and proximate bases. Behavioral and Brain Sciences, 25, 1-20.

Reniers, R. L., Corcoran, R., Drake, R., Shryane, N. M., \& Völlm, B. A. (2011). The QCAE: A questionnaire of cognitive and affective empathy. Journal of personality assessment, 93(1), 84-95.

Rice, G. E. (1964). Aiding behavior vs. fear in the albino rat. The Psychological Record, 14(2), 165-170.

Rice, G. E., \& Gainer, P. (1962). “Altruism” in the albino rat. Journal of comparative and physiological psychology, 55(1), 123.

Samsunhaber, (2020, 19 Kasım). Vali Dağlı ayakları kesilen yavru köpek olayına el attı. Erişim adresi: https://www.samsunhaber.com/samsun-haber/vali-dagli-ayaklarikesilen-yavru-kopek-olayina-el-atti-h61186.html.

Segesten, A. D., \& Bossetta, M. (2017). A typology of political participation online: How citizens used Twitter to mobilize during the 2015 British general elections. Information, Communication \& Society, 20(11), 1625-1643.

Stern, J. A., Botdorf, M., Cassidy, J., \& Riggins, T. (2019). Empathic responding and hippocampal volume in young children. Developmental Psychology, 55(9), 1908.

Stotland, E. (1969). Exploratory investigations of empathy. In Advances in experimental social psychology (Vol. 4, pp. 271-314). Academic Press.

Thompson, R. A. (1987). Empathy and emotional understanding: The early development of empathy. Empathy and its development, 119-145.

Titchener, E. B. (1909). Elementary psychology of the thought processes. New York: Macmillan.

Titchener, E. B. (1915). A Beginner's psychology. (E-kopya-2016). New York: The Macmillan Company.

Watanabe, S. \& Ono, K. (1986). An experimental analysis of "empathic" response: Effects of pain reactions of pigeon upon other pigeon's operant behavior. Behavioural Processes 13:269-77.

WeAre Social, (2021a). Digital around the World. Erişim Adresi: https://wearesocial. com/digital-2021. Erişim Tarihi: 4.05.2021. 
Weitzenfeld, A., \& Joy, M. (2014). An overview of anthropocentrism, humanism, and speciesism in critical animal theory. Counterpoints, 448, 3-27.

Wind, E. (1963). Art and anarchy. London: Faber \& Faber.

Wispe, L. (1986). The distinction between sympathy and empathy: To call forth a concept a Word is needed. Journal of personality and social psychology, 50(2), 314-321).

Destekleyen Kurum/Kuruluşlar: Herhangi bir kurum/kuruluştan destek alınmamıştır.

Çıkar Çatışması: Herhangi bir çıkar çatışması bulunmamaktadır. 